VANDA LAMM*

\title{
The Multilateral Treaty Reservation Revisited
}

\begin{abstract}
In the State practice regarding the declarations of acceptance of the International Court's compulsory jurisdiction one can trace some disputed reservations containing proviso which undermine the obligation assumed regarding the Court's compulsory jurisdiction. One of the limitations is called reservation concerning multilateral treaty, otherwise known as the Vandenberg reservation or multilateral treaty reservation.

The article treats these reservations by examining their origin, contents and Court's jurisprudence on the matter.

According to the author the multilateral treaty reservations have destructive effect on the compulsory jurisdiction system, chiefly because the broad conception of interpretation of the "affected" States bars proceedings before the Court over disputes as to multilateral treaties concluded by a larger group of States, if not all the States party to the treaty are also parties in the proceedings before the Court. As for the other part of the reservation, that stipulation virtually invalidates the obligations assumed in declarations of acceptances, since it hampers the Court to deal with a dispute submitted to it unless the State making such a reservation in its declaration or, on the basis of reciprocity, the adverse party has agreed to the Court's jurisdiction. The adverse effect of the reservation is all the more so since the multilateral treaty reservations expressly concern disputes with regard to treaty interpretation, and considerable part of the cases brought before the Court concern precisely such disputes.
\end{abstract}

Keywords: multilateral treaty reservation, Vandenberg reservation, International Court of Justice, declarations of acceptance, optional clause

The more than eighty years of State practice and the jurisprudence of the two World Courts revealed that States, while accepting the compulsory jurisdiction of the International Court of Justice or its predecessors that of the Permanent Court of International Justice, join to their declarations of acceptance such reservations or limitations which raise the question whether the given State had made a real commitment toward the compulsory jurisdiction of the Court. In the literature of international law one of these limitations is called reservation concerning multilateral treaty, otherwise known as the Vandenberg reservation or multilateral treaty reservation, hereinafter for the sake of abbreviation we will use the term of "multilateral treaty reservation".

Director, Institute for Legal Studies of the Hungarian Academy of Sciences, H-1250 Budapest, POB 25; Professor, Széchenyi István University, Győr.

E-mail: lamm@jog.mta.hu 


\section{Appearance of the reservation}

The appearance of multilateral treaty reservation is linked up with the 1946 United States' declaration under the optional clause accepting the compulsory jurisdiction of the International Court of Justice. ${ }^{1}$

The origin of this limitation can be traced to the Memorandum which John Foster Dulles-head of the United States delegation to the United Nations General Assembly and later Foreign Secretary of State-sent to a subcommittee of the Foreign Affairs Committee of the s Senate on 10 July 1946. In his Memorandum Dulles explained that in case of disputes as to multilateral treaties it was possible that a matter at issue in the case might arise in relations not only between two States party to the given multilateral treaty and being in the case parties before the Court, but also between the other contracting parties to that treaty. In view of such matters it would be necessary to make clear that it was not compulsory to submit to the Court a dispute as to the given multilateral treaty solely on the ground that certain States party to the treaty were required to do so under the optional clause, the reason being that the other States party to the treaty had not undertaken to resort to the Court and thereby to become parties, so they were not bound by Article 94, of the Charter providing that each Member of the United Nations "undertakes to comply with the decision of the International Court of Justice in any case to which it is a party". ${ }^{2}$ It was on the basis of the Dulles Memorandum that on the proposal of Senator Vandenberg the Senate decided to also include in the United States declaration of acceptance the limitation that there should be excluded from the Court's compulsory jurisdiction

"disputes arising under a multilateral treaty, unless (1) all Parties to the treaty affected by the decision are also Parties to the case before the Court, or (2) the United States of America specially agrees to jurisdiction".

1 The United States of America was not a member of the optional clause system of the Permanent Court of International Justice. In 1946 the Washington Government the first time made a declaration under Article 36, paragraph 2 of the Statute.

${ }^{2}$ On the Dulles Memorandum compare and see Anand, R. P.: The Compulsory Jurisdiction of the International Court of Justice. New York, 1961. 220.; and Briggs, H. W.: Reservations to Acceptance of Compulsroy Jurisdiciton of the International Court of Justice. Recueil des Cours, 1958. 306-307. According to Briggs, Hudson called the Dulles Memorandum "a jumble of ideas". 
It was characteristic of the Senators that, as is pointed out by Briggs, they had adopted the reservation without clarifying debate and without understanding its meaning and implications. ${ }^{3}$

According to Judge Ruda, Washington Government intended, by making that reservation, to avoid a situation in which it would be obliged to apply a multilateral treaty in certain way in line with the Court's judgement, while the other States party to the treaty and not participating in the proceedings remained free, to apply the treaty in different ways from that determined by the judgement of the Court, since according to Article 59, of the Statute the decision of the Court has no binding force except between the parties and in respect of the particular case. ${ }^{4}$

Relying on the related Senate documents, Maus writes that the Senators were not aware at the time of the reservation's modifying the jurisdiction already conferred to the Court and believed that by making that reservation they actually settled an issue. ${ }^{5}$ However, the solution of the problem is out of the question, for the reservation is vague and, as will be seen later, lends itself to various interpretations.

For that matter, Kelsen asserts that the wording of the reservation was modelled on Article 62, paragraph 1, of the Statute, which refers to "an interest of a legal nature which may be affected by the decision in the case", having the meaning that all parties to the multilateral treaty which may be affected by the decision of the Court are also parties to the case before the Court. ${ }^{6}$

The example of the American declaration of acceptance was followed by other States, with certain variations of the reservation found in several declarations accepting compulsory jurisdiction. ${ }^{7}$

3 Briggs: op. cit. 307.

4 Case concerning Military and Paramilitary Activities in and against Nicaragua (Jurisdiction of the Court and Admissibility of the Application), Judgement of 26 November 1984. Separate Opinion of Judge Ruda. ICJ Reports, 1984. 456.

5 Maus, B.: Les réserves dans les declarations d'acceptation de la jurisdiction obligatoire de la Cour internationale de Justice. Genéve, 1959. 165.

6 Kelsen, H.: The Law of the United Nations. London, 1951. 530.

7 On this score see the declarations of acceptance by France (1947), India (1956), Liberia (1952), Malawi (1966), Mexico (1947), Pakistan (1948), The Philippines (1972), South Africa (1955) and The Sudan (1958). 


\section{The notion problem of "being affected"}

The multilateral treaty reservation, given its uncertainty and vagueness, was criticized by numerous author in the literature on international law. What was most frequently written in criticism was that the reservation withdrew, at the will of the United States, a large fraction of legal disputes arising under multilateral treaties covered by the optional clause. ${ }^{8}$

The vagueness of the reservation is manifested chiefly in the first part of the limitation and is linked to the phrase "all Parties to the treaty affected by the decision are also Parties to the case before the Court". This passage raises two problems. The first concerns the question of who or what should be understood by the word "affected": all the parties to the treaty or the multilateral treaty?" If the reference is to the parties, an answer should be given to the question of when a party to the treaty is to be deemed "affected". ${ }^{10}$ If, on the other hand, it is the treaty that is to be considered "affected", then "affected" are, under the reservation, all parties to the treaty and hence all of them should participate in the proceedings before the Court. In other words, it is not clear whether the drafters of the Vandenberg reservation had in mind the participation in proceedings, over a dispute arising under a multilateral treaty, of all parties to that treaty or only of the parties affected by the dispute. This possibility of two different interpretations allows of a narrow and a broadly conception of the reservation, depending on whether the reference is to all parties to a multilateral treaty or only to the States affected by the dispute.

If the drafters of the reservation wanted to secure participation in the proceedings of all parties to a multilateral treaty, attainment of that aim is next to impossible in practice, since it would call for ensuring the presence of as many as 50 or 100 States before the Court, the examination of their written submissions, etc. This in turn would present a task almost impossible to perform, let alone the uncertainty surrounding the intention of all States party to the treaty to become parties to the case before the Court, for it may well be imagined that several contracting parties have no interest whatever in having the given dispute decided by the Court. All these aspects may combine to result in that a dispute as to, for instance, the United Nations Charter or some other major multilateral treaty will in fact never be dealt with by the Court.

Waldock, C. H. M: Decline of the Optional Clause. The British Year Book of International Law. 1954. 275.

${ }^{9}$ Cf. Kelsen: op. cit. 530.

${ }^{10}$ Anand: op. cit. 222. 
During; the 1970s the multilateral treaty reservations came to be formulated in clearer terms. Thus, for instance, the declarations of El Salvador (1973), India (1974) and The Philippines (1972) contain the literally uniform text "all parties to the treaty are parties to the case before the Court". ELL . In this way the said reservations make it unambiguously clear that all States party to the multilateral treaty are to participate in the proceedings before the Court, which is to say that the States mentioned above included in their respective declarations of acceptance the broad conception of the reservation. In connection with these reservations I should like to refer to a statement by Judge Sette-Camara in the Case concerning Military and Paramilitary Activities in and against Nicaragua (Nicaragua v. United States); he observed that the broad conception of the reservation might have rather far-reaching consequences and that such reservations would require the appearance before the Court all member States of the United Nations and of the Organization of American States, e.g., the Nicaragua Case, together with the original parties in the case. ${ }^{11}$

Judge Sir Robert Jennings, in his separete opinion delivered on the preliminary objections in that same case termed as bizarre the idea for as many as 20 to 30 States to participate in the proceedings, but, for all that, he considered that the declarant State was entitled to make such a reservation, the practical result is, that the Court had no jurisdiction in the absence of special agreement. ${ }^{12}$ In his dissenting opinion joined to the judgement on the merits of the case the British Judge emphasised that, in spite of the difficulties connected with the reservation, the Court was under obligation to respect it and apply it. ${ }^{13}$

\section{Problems concerning participation of third States in the proceedings}

Those who are defending the Vandenberg reservation are usually arguing that this limitation serves to defend the interests of third States party to a given multilateral treaty. Such reasoning is not convincing because Articles 62, and 63, of the Statute expressly provide for safeguarding the interests of third States

${ }^{11}$ Cf. Case concerning Military and Paramilitary Activities in and Against Nicaragua (Merits) Judgement of 27 June 1986. Separate Opinion of Judge Sette-Camara. ICJ Reports, 1986. 192.

${ }^{12} \mathrm{Cf}$. Case concerning Military and Paramilitary Activities in and against Nicaragua (Jurisdiction of the Court and Admissibility of the Application), Judgement of 26 November 1984. Separate Opinion of Judge Sir Robert Jennings. ICJ Reports, 1984. 554.

${ }^{13}$ Case concerning Military and Paramilitary Activities in and against Nicaragua (Merits), Judgement of 27 June 1986. Dissenting Opinion of Judge Sir Robert Jennings. ICJ Reports, 1986. 529. 
by entitling those States to intervene in the proceedings before the Court. Therefore, as is rightly stated by Verhoeven, the reservation defends the interests of only one State, that which has written the reservation into its declaration of acceptance. $^{14}$

A closer look at multilateral treaty reservations leads us to make the point that in certain cases safeguarding of the interests of third States may prove all too strong an asset, since a State or States party to the multilateral treaty may happen to have no interest whatever in having a dispute regarding the interpretation or application of the treaty decided by the Court. On a broader conception of the Vandenberg reservation, the consent even of these States is required to proceedings before the Court, yet, under the reservation, these States are not obliged to participate in the proceedings, that is to say that they may refuse their participation. By so doing they undoubtedly defend their own interests, but, at the same time, they prejudice the interests of those States party to the treaty which, on the other hand, seek to have the dispute to be decided by the Court. At any rate, the reservation gives States a measure of manoeuvre to decide by themselves, despite their commitment undertaken in respect to the compulsory jurisdiction of the International Court of Justice and actually on a case-by-case basis, whether a particular legal dispute may be dealt with by the Court.

In exploring a solution to these problems arising out of the Vandenberg reservation Louis Sohn suggested that the reservation should be reworded ${ }^{15}$ to exclude from compulsory jurisdiction "disputes relating to a multilateral treaty, unless all the parties to that treaty have agreed that any decision rendered in any such dispute between two or more of them will be binding upon all of them ..." (my emphasis-V. L.). ${ }^{16}$ Lori Damrosch is critical of Sohn's suggestion, which she believes to have more disadvantages than advantages, and she raises the question of its compatibility with Article 94, of the United Nations Charter and Article 59, of the Court's Statute. The American professor is of the view that Sohn's proposal purports to derogate from the binding

${ }^{14} \mathrm{Cf}$. Verhoeven, J.: Le droit, le juge et la violence. Revue général de droit international. 1987. 1177.

${ }^{15}$ After the withdrawal in 1986 of the United States declaration of acceptance of 1946 experts of international law have written widely on what the new United States declaration of acceptance should contain, a draft of a new declaration prepared by Professor Louis Sohn.

${ }^{16}$ On Sohn's draft see Sohn, Louis B.: Compulsory Jurisdiction of the World Court and the United States Position: The Need to Improve the United States Declaration. In: Clark Arend, A. (ed.): The United States and the Compulsory Jurisdiction of the International Court of Justice. University Press of America, 1986. 3-28. 
character of the Court's decisions in contentious cases, because the unanimous consent as mentioned in the proposal can hardly be expected to be given by States with no interest in a particular matter. ${ }^{17}$ Damrosch also tries to remedy the problems caused by the reservation by suggesting a formula that would deny the United States consent to jurisdiction if the case "concern the interests of third States". ${ }^{18}$

Within the meaning of the Statute and the Rules of Court, intervention in the proceedings is the legal institution through which a third State may participate in contentious case before the Court in defence of its own interests. Without dwelling on questions of intervention in cases before the Court we can state that there exist in fact two ways of intervention, depending on whether intervention is based on Article 62, or Article 63, of the Statute. ${ }^{19}$ Under Article 62, States are empowered to intervene in a case if they consider that a legal interest of theirs may be affected, in that case the State may submit a request to the Court to be permitted to intervene. The permission may be granted or refused, upon the decision of the Court, considering whether or not the intervening State's legal interests are affected by the proceedings instituted.

0n the other hand, Article 63, covers precisely a case which involves the interpretation of a multilateral treaty before the Court and in which, along with the disputants, the other States party to the treaty are permitted to intervene. ${ }^{20}$ Intervention under Article 63, thus accords to the States party to a multilateral treaty the right to intervene.

Participation by third States in the proceedings before the Court under the Vandenberg reservation has some similarities with intervention under Article 63. Nevertheless, there are significant differences between the two situations.

(a) According to the Vandenberg reservation proceedings before the Court cannot take place unless the other States party to a multilateral treaty also participate therein-and the question of whether those States are affected by the decision of the Court or they include all States party to the multilateral treaty

${ }^{17}$ Cf. Damrosch, Lori F.: Multilateral Disputes. In: Damrosch (ed.): The International Court of Justice at a Crossroads. New York, 1987. 398.

${ }^{18}$ Ibid. 399.

${ }^{19}$ On this score see Ruda, J. M.: Intervention before the International Court of Justice. In: Lowe, V.-Fitzmaurice, M. (ed.): Fifty Years of the International Court of Justice. Essays in honour of Sir Robert Jennings. Cambridge, 1996. 487-502.

${ }^{20}$ Article 63, reads as follows: " 1 . Whenever the construction of a convention to which states other than those concerned in the case are parties is in question, the Registrar shall notify all such states forthwith. 2 . Every state so notified has the right to intervene in the proceedings; but if it uses this right, the construction given by the judgement will be equally binding upon it". 
is of no relevance here-, the reservation practically exercises some sort of pressure on these States to participate in the proceedings, because the Court cannot decide on the legal dispute without their presence. By contrast, in the case of intervention under Article 63, of the Statute, it is exclusively for the affected State to decide whether to make use of its right to intervene.

(b) Under the general rule governing intervention it is for the Court to decide on intervention, even in the case of intervention under Article 63, since the treaty to be interpreted is determined by the Court, whereas under the Vandenberg reservation the Court is actually left without discretion to decide on the participation in the proceedings of States other than the original parties, because the reservation makes it to some extent an obligation of the States affected to participate in the proceedings or else the proceedings before the Court cannot take place at all.

In connection with the Vandenberg reservation the question also arises of what will be the position in the proceeding of the other States party to the multilateral treaty. This is an open question, all the more so since the position in the proceedings of the intervening State is similarly awaiting full clarification.

It was in 1992, for the first time during the existence of the International Court of Justice, that the Court permitted a third State to intervene in the Case concerning the Land, Island and Maritime Frontier Dispute (El Salvador v. Honduras). Until this case the literature on international law was also rather uncertain about the position in the proceedings of the intervening State. ${ }^{21}$ Precisely for that reason the Court, when it permitted to Nicaragua's intervention in the dispute between El Salvador and Honduras, ${ }^{22}$ found it necessary to make certain statements concerning the status of the intervening State in the case. $^{23}$

The Court held that the intervening State does not become a party to the proceedings and does not aquire the rights or become the subject of the obligations pertaining to parties under of the Statute, the Rules of Court, or general principles of procedural laws. At the same time, however, the intervening State is also vested with certain rights, such as the submission of a written statement and right to be heard. ${ }^{24}$

${ }^{21}$ Cf. Davi, A.: L'intervento davanti alla Corte Internazionále di Giustizia, Napoli, 1984. 209-215.

${ }^{22}$ For that matter, the case involved intervention under Article 62, of the Statue.

${ }^{23}$ Case concerning the Land, Island and Maritime Frontier Dispute (Application by Nicaragua for Permission to Intervene), Judgement of 13 September 1990. ICJ Reports, $1990,135$.

${ }^{24}$ Ibid. 1990. 135-136. 
In respect to reservations concerning multilateral treaties this means that, on a broad conception of the reservation, for instance, all States party to multilateral treaty (which may number 30 or 40 or even more) should participate in proceedings over a particular case, all invested with the right to be heard by the Court! It needs no further explanation that this would not be a viable path in practice.

If, on the other hand, the intervening State being a non-party in the case, the Court's decision is not binding on it. In the Case concerning the Land, Island and Maritime Frontier Dispute this reasoning was also practically upheld by the ad hoc chamber, composed of members of the Court, in dwelling on the question of res judicata and Article 59, of the Statute. ${ }^{25}$ In dealing with this matter Rosenne points out-along lines similar to the declaration, made by Judge Oda and attached to the judgement of 11 September $1992,{ }^{26}$-that, since that case concerned a territorial dispute, the Court's judgement was binding not only on the parties, but is valid erga omnes. Precisely for this reason, the Israeli professor stated that it was difficult to understand why the chamber did not somehow written into the judgement Nicaragua's declaration, made at the time of submitting its request for intervention, that it would abide by the terms of the judgement. $^{27}$

In respect of the Vandenberg reservation all this leads to the conclusion that if the Court should be seized on the basis of a multilateral treaty's compromissory clause and the States party to the treaty also wishing to participate in the proceedings before the Court under the terms of the Vandenberg reservation, it can be taken as very likely that, having regard to the judgement in the Case concerning the Land, Island and Maritime Frontier Dispute, these States would be considered by the Court as non-parties in the proceedings and would also not be bound by the judgement of the Court. It is not sure, of course, that in a dispute as to a multilateral treaty the Court would by analogy apply its legal practice with regard to intervention, while it is unlikely that under the Vandenberg reservation the Court would recognize for third States participating in a case more rights than it had conceded to the intervening State in the Case concerning the Land, Island and Maritime Frontier Dispute.

${ }^{25}$ Case concerning the Land, Island and Maritime Frontier Dispute. Judgement of 11 September 1992. ICJ Reports, 1992. 135.

${ }^{26} \mathrm{Cf}$. Ibid. Declaration of Judge Oda. 619-620.

${ }^{27}$ Rosenne, Sh.: Intervention in the International Court of Justice. Dordrecht, Boston, London, 1993. 155. 


\section{The question of consent to proceeding}

The second part of multilateral treaty reservation, as contained in the United States declaration of acceptance and stipulating in fact an alternative condition, provides that in a dispute arising under a multilateral treaty the Court may not have jurisdiction "unless the United States of America specially agrees to jurisdiction". This practically means nothing else than that disputes as to multilateral treaties cannot be brought before the Court solely under the optional clause and that the consent of the State including the Vandenberg reservation in its declaration of acceptance-and, on the basis of reciprocity, that even of the adverse party-is required to proceedings in related matters.

Hudson asserts that this clause of the reservation shows a confusion of thought, for if the United States agrees to jurisdiction, it is virtually that consent which, functioning, as it were, as a special agreement, constitutes the basis for the Court's jurisdiction, and therefore the question does not even emerge of the application of the declaration of acceptance. ${ }^{28}$ One can say that in respect of the reservation it is unclear whether the special consent of the United States practically replaces the declaration of acceptance and that lack of its consent entails disregard of the Court's compulsory jurisdiction in disputes arising under multilateral treaties. According to Waldock, the reservation practically operates to preclude the United States from being brought before the Court in a dispute as to a multilateral treaty unless the United States specifically consents to jurisdiction after the case has arisen. ${ }^{29}$

In respect of multilateral treaty reservation the question also arises of how reciprocity affects this limitation, especially that part of it which requires even a separate consent of the declarant State to the Court's jurisdiction, since according to the principle of reciprocity a reservation may be invoked by the opponent party as well. This entails that the reservation in a concrete case should be applied as if the party referring to it has also attached to the declaration of acceptance the clause that, in addition to the declaration accepting compulsory jurisdiction, its separate consent is required to the Court's jurisdiction over disputes arising under multilateral treaties. One can conclude that the reservations concerning multilateral treaties, in combination with the principle of reciprocity, nullify the obligations undertaken with regard to the Court's compulsory jurisdiction, not only of the States including such limitation in

\footnotetext{
${ }^{28}$ Hudson World Court-America's Declaration Accepting Jurisdiction. 32 A. B. A. Journal (1946) 836. Quoted by Anand: op. cit. 221.

${ }^{29}$ Waldock: op. cit. 274.
} 
their declarations of acceptance, but in concrete cases the opponent party's commitment regarding compulsory jurisdiction as well.

\section{The reservation in the practice of the Court}

In the jurisprudence of the International Court of Justice the reservations concerning multilateral treaties were considered for the first time in the Case concerning Military and Paramilitary Activities in and against Nicaragua. ${ }^{30}$

In its memorandum presented in response to Nicaragua's application and in the course of the oral proceedings the United States advanced the point that Nicaragua had invoked in its application four multilateral treaties, the United Nations Charter, the Charter of the Organization of American States, the 1933 Montevideo Convention on Rights and Duties of States and the Havana Convention on the Rights and Duties of States in the Event of Civil Strife. The Washington Government argued that since the dispute submitted to the Court "had arisen" under the treaties listed, the Court, under the Vandenberg reservation contained in the United States declaration of acceptance, may exercise jurisdiction only if all treaty parties affected by a prospective decision of the Court are also parties to the case. For its part, the American Government did name the said States (Costa Rica, El Salvador and Honduras) and maintained that if a single one of them was found by the Court to be "affected", the United States reservation was to come into play. ${ }^{31}$

In its judgement on the preliminary objections the Court itself acknowledged that the multilateral treaty reservation attached to the United States declaration of acceptance was vague and lent itself to two different interpretations: "It is not clear whether what are "affected", according to the terms of the proviso, are the treaties themselves or the parties to them". ${ }^{32}$ So, in fact, the Court did nothing else than repeat the questions formulated in the literature of international law with respect to the reservation. Those questions were not, however, answered by the Court, and that for two reasons. First, because,

${ }^{30}$ On this aspects of Nicaragua case see: Alexandrov, Stanimir A.: Reservations in Unilateral Declarations Accepting the Compulsory Jurisdiction of the International Court of Justice. Dordrecht-Boston-London, 1995. 112-119.

${ }^{31}$ Case concerning Military and Paramilitary Activities in and against Nicaragua. ICJ Pleadings. vol. II. Cf. USA Counter-Memorial. Part III. 74-97.

${ }^{32}$ Case concerning Military and Paramilitary Activities in and against Nicaragua (Jurisdiction of the Court and Admissibility of the Application), Judgement of 26 November 1984. ICJ Reports, 1984. 424. 
according to the judgement, the reservation had been interpreted by the United States itself as applying only to States affected by the decision (i.e. Washington sought to apply the narrow conception of the reservation) and the three neighbouring States that might be affected had also been indicated by Washington. ${ }^{33}$ Second, the Court found that the reservation concerning multilateral treaties did not affect its jurisdiction in that case, as Nicaragua invoked a number of principles customary and general international law, which have been enshrined in the text of the convention relied upon by Nicaragua. The Court emphasized:

"The fact that the above mentioned principles, recognized as such, have been codified or embodied in multilateral conventions does not mean that they cease to exist and to apply as principles of customary law, even as regards countries that are parties to such conventions." ${ }^{34}$

By taking this view the Court actually escaped application in the concrete case the multilateral treaty reservation.

Over and above these points the Court's judgement covered the question of who vas to decide whether a State was or was not "affected", according to the terms of the proviso, by a future decision of the Court. The Court held that should a State consider itself affected by the decision, it would either file an application itself or would submit a request for intervention.

The Court could identify the States "affected" only when the general outline of judgement to be given become clear. "Certainly the determination of the States 'affected' could not be left to the parties but must be made by the Court". "This line of the Court's reasoning is similar to that of Kelsen, who, shortly after the Vandenberg reservation had appeared, wrote that the question of which States were affected by a decision of the Court can be decided "only after the Court had assumed and exercised jurisdiction in the dispute concerned". ${ }^{37}$

\footnotetext{
${ }^{33}$ For that matter, the United States did not but merely mention the other possible construction of the reservation, namely that which required participation in the proceedings of all States party to the multilateral treaties indicated.

${ }^{34}$ Case concerning Military and Paramilitary Activities in and against Nicaragua (Jurisdiction of the Court and Admissibility of the Application), Judgement of 26 November 1984. ICJ Reports, 1984. 424.

${ }^{35}$ Ibid. 425.

${ }^{36}$ Ibid.

${ }^{37}$ Kelsen: op. cit. 530.
} 
The question of "affected" States was likewise considered by the Court in dealing with the merits of the case, namely in the context of the extent to which the Court's decision affected the rights of El Salvador and hence the Salvadorian State itself in the concrete case. ${ }^{38}$ The United States did not participate in that phase of the proceedings, but the Court considered at length the United States' contention based on multilateral treaty reservation. ${ }^{39}$ In connection with the Vandenberg reservation the Court stated that

“... the reservation does not require, as a condition for the exclusion of a dispute from the jurisdiction of the Court, that a State party to the relevant treaty be 'adversely' or 'prejudicially' affected by the decision, even though this is clearly the case primary at view."

In other words, application of the reservation does not require determining whether the State is unfavourably or otherwise "affected"; "the condition of the reservation is met if the State will necessarily be 'affected', in one way or the other" ${ }^{41}$ The Court held that in the concrete case the multilateral treaty reservation operated as a bar to certain documents being invoked as multilateral treaties, but it did not in any way affect the consideration of Nicaragua's claims based on other sourcess international law. ${ }^{42}$ That is to say according to the Court, it had jurisdiction under Article 36, paragraph 2, of the Statute to consider Nicaragua's claims based upon customary international law, but it should exclude from its jurisdiction of disputes "arising under" the United Nations and the Organization of American States Charters. ${ }^{43}$ As for this finding,

${ }^{38}$ In that case Washington contended that by the American activities carried out in El Salvador and protested against by Nicaragua it had exercised the right of collective selfdefence from a possible armed attack by Nicaragua and that collective self-defence was recognized by the Charter of the United Nations as well as by the Charter of the Organization of American States. Therefore the dispute under consideration had arisen under multilateral treaties, to which El Salvador was also a party along with the United States and Nicaragua. Cf. Case concerning Military and Paramilitary Activities in and against Nicaragua. ICJ Pleadings. vol. II. 86-91.

${ }^{39}$ On this score see the author’s Gondolatok a Nemzetközi Biróság eljárásától való távolmaradásról (Reflections on the Non-appearance before the International Court of Justice). Állam- és Jogtudomány, 1982. 21-40.

${ }^{40} \mathrm{Cf}$. Case concerning Military and Paramilitary Activities in and against Nicaragua (Merits), Judgement of 27 June 1986. ICJ Reports, 1986. 37.

${ }^{41}$ Ibid.

${ }^{42}$ Ibid. 38.

${ }^{43}$ Ibid. 97. 
Judge Oda, in his dissenting; opinion joined to the judgement, expressed the view that the Court should have proved, not that it can apply customary and general international law independently, but that Nicaragua's claims, had not arisen under these multilateral treaties" (the above-mentioned two multilateral treaties-V. L.). ${ }^{44}$

At any rate, the Court's decision on the merits of the Nicaragua Case similarly failed to answer several important questions relating to multilateral treaty reservations, and, as is pointed out by Briggs, the Court disregarded the fact that a reservation stipulating that "all States party to a multilateral treaty and affected by the decision shall also participate in the proceedings" has a destructive effect on international adjudication and is incompatible with the Statute of the Court. Instead, the Court stuck to the term "affected State" without thoroughly examining whether El Salvador's rights were affected by the case at all or what was meant by that term in the context of Article 59, of the Statute, which provides that the decision of the Court has no binding forte except between the parties and in respect of that particular case. ${ }^{45}$ According to the well-known British expert, the Court was content to merely state that El Salvador was "affected", but it did not say the same in respect of Honduras, albeit that country was the base of the operations against Nicaragua. ${ }^{46}$

In recent years the other case before the International Court of Justice, the Case concerning the Aerial Incident of 10 August 1999 (Pakistan v. India), similarly involved multilateral treaty reservations. In response to the Pakistan's application India filed preliminary objection invoking, inter alia, the fact that its declaration of acceptance of 1974 contains the multilateral treaty reservation, which bars Pakistan from invoking the Court's jurisdiction against India "concerning any dispute arising from the interpretation or application of a multilateral treaty, unless at the same time all the parties to such a treaty are also joined as parties to the case before the Court". India contended that the United Nations Charter, on which Pakistan founded its claims, belonged exactly to the category of multilateral treaties to which the reservation applied. Apart from this, India gave no consent to anything and signed with Pakistan no special agreement derogating from the content of the reservation.

The multilateral treaty reservation was not considered in the case since, as mentioned earlier, the Court based itself an the Commonwealth reservation

${ }^{44}$ Ibid. Dissenting Opinion of Judge Oda. 219.

${ }^{45}$ Briggs, H. W.: The International Court of Justice Lives up to its Name. American Journal of International Law, 1987. 81.

${ }^{46}$ Ibid. 
joined to the Indian declaration of acceptance and found that it had no jurisdiction to entertain the application filed by the Islamic Republic of Pakistan. ${ }^{47}$

From the foregoing it becomes clear that the multilateral treaty reservations have destructive effect on the compulsory jurisdiction system, chiefly because the broad conception of interpretation of the "affected" States bars proceedings before the Court over disputes as to multilateral treaties concluded by a larger group of States. As for the other part of the reservation, the said stipulation virtually invalidates the obligations assumed in declarations of acceptances, since it hampers the Court to deal with a dispute submitted to it unless the State making such a reservation in its declaration or, on the basis of reciprocity, the adverse party has agreed to the Court's jurisdiction. All this is detrimental to judicial settlement of international disputes, all the more so since the multilateral treaty reservations expressly concern disputes with regard to treaty interpretation, and considerable part of the cases brought before the Court involves precisely such disputes.

\section{The Vandenberg reservation and the Statute}

With regard to the reservations to declarations of acceptance one can meet with views expressed both before the Court and in the literature of international law to the effect that this or that reservation is "incompatible with the Statute". References to incompatibility with the Statute appear to suggest that what we have are reservations to the Statute, although limitations to declarations of acceptance can in no way be considered as reservations to the Statute. Declarations of acceptance are unilateral acts with proviso freely made up by States. Yet, no matter how free States may be to introduce conditions for or limitations to their declarations of acceptance, these declarations may not contradict to the Statute and must be in line the UN Charter, the Statute and the Rules of Court. While in several cases the Court has more or less clarified the question of incompatibility of certain reservations with the Statute, it did not give answer to the question of compatibility with the Statute of the truly "problematical" reservations, namely, among others, the multilateral treaty reservations.

The question of compatibility with obligations under the Statute and the optional clause arises in connection with multilateral treaty reservations, both with the first part of the reservation on account of its vagueness, as has been discussed already, and with the second part thereof, which requires the decla-

${ }^{47}$ Case concerning Aerial Incident of 10 August 1999 (Jurisdiction of the Court) Judgement of 21 June 2000. ICJ Reports, 2000. para. 46. 
rant State's special consent to the jurisdiction of the Court. This part of the reservation is clearly contrary to the obligations under Article 36, paragraph 2, of the Statute and even to the spirit of the optional clause, namely that States declare to recognize "ipso facto" and without special agreement the jurisdiction of the Court.

Owing to the second part of the Vandenberg reservation the parties' declarations of acceptance become purposeless, the Court's compulsory jurisdiction cannot come into play in disputes as to multilateral treaties, and such disputes cannot be considered by the Court unless the State including this reservation in its declaration-and, on the basis of reciprocity, the opponent party-specially agree to submit the dispute to the Court.

By this part of the multilateral treaty reservation the declarant State takes back the compulsory jurisdiction which it conferred on the Court by its accession to the optional clause system. Practically such is the case with the automatic or subjective domestic reservations the so called Connally reservations as well. This is perhaps even more readily perceptible with multilateral treaty reservations than with subjective domestic jurisdiction reservations, for if in a legal dispute before the Court the State entitled decides not to invoke the subjective domestic jurisdiction reservation, the Court may go on with the proceedings without further consideration, as the application of the reservation is not automatic and parties should refer to it before the Court. In the case of multilateral treaty reservations the parties have no such "discretion" and, if one clings strictly to the wording of the reservation, the Court may not, in matters covered by the reservation, assume jurisdiction unless the parties specially agree thereto. Of course, multilateral treaty reservations may also happen not to be invoked, but in that event the Court's jurisdiction is practically founded not on the declaration of acceptance, since under the reservation joined to the declaration the Court could not deal with the particular matter in any way, but on the forum prorogatum, i.e. on the parties' consent to jurisdiction given in the process.

\section{Has the invalidity of the reservation any effect on the declaration as a whole?}

In connection with multilateral treaty reservations the question arises of whether these reservations are valid at all and whether the eventual invalidity thereof carries implications for the declaration of acceptance itself.

Both the views of the judges of the International Court of Justice and the position of the literature of international law are divided as to the extent to 
which an invalid reservation affects the declaration of acceptance itself. On one view, invalidity bears upon the declaration of acceptance as a whole, whereas on the other view invalidity has no effect on the declaration itself.

The question of separability of an invalid clause from the rest of the declaration arise in connection with the reservations concerning multilateral treaties, but this set of problems has received much less attention than the subjective domestic jurisdiction reservations have. In the Nicaragua Case Judge Mosler asks whether the declaration of acceptance as a whole is affected by the invalidity of the reservation. ${ }^{48} \mathrm{He}$, too, leaves this question unanswered, however, and the German Judge confines himself to stating that "If an affirmative conclusion were to be taken, its effect would be worse than to apply the reservation and to maintain the rest of the declaration". ${ }^{49}$ In his separate opinion Judge Jennings dwells on whether the difficulties concerning the uncertainty of the exact meaning of the reservation do not render the whole reservation so vague that it can be discarded, which, however, leads on to the other question whether, since the reservation might be not severable from the declaration, it might render the entail American declaration of acceptance void. ${ }^{50}$

We, for our part, are of the view that the authors claiming that an invalid clause has no bearing on declarations of acceptance of compulsory jurisdiction or on the reservation itself and that, apart from the invalid part, the rest of the declaration of acceptance remains operative are not proved right. If a reservation or a clause attached to a declaration of acceptance is deemed nonexistent, while the rest of the declaration is recognized as valid, the obligations of the declarant State are increasing without the consent thereof, which contradicts to the jurisprudence of the two International Courts, that jurisdiction exists only within the limits expressly accepted by the parties and that it should be interpreted in a narrow sense. This was expressed in the judgement of the Permanent Court of International Justice in the Chorzów Factory Case and reiterated by both Courts in several other cases, stating that "... the Court's jurisdiction is always a limited one, existing only in so far as States have accepted it...." 51

${ }^{48}$ Case concerning Military and Paramilitary Activities in and against Nicaragua (Jurisdiction of the Court and Admissibility of the Application), Judgement of 26 November 1984. Separate Opinion of Judge Mosler. ICJ Reports, 1984. 469.

${ }^{49}$ Ibid.

${ }^{50}$ Separate Opinion of Judge Sir Robert Jennings. Ibid. 554-555.

${ }^{51}$ German Interests in Polish Upper Silesia and the Factory and Chorzów. Judgement (Jurisdiction), July 26, 1927. Hudson, M. O. (ed.): World Court Reports, 1920-1942. New York, 1972. vol. I. 610. 


\section{Effect of the Court's eventual, nullity decision}

It would be primarily for the Court to decide the open questions concerning disputable reservations and their compatibility with the Statute. However, as the foregoing go to show clearly, in dealing with a variety of matters the Court has in fact avoided giving answers to these questions.

As mentioned already, the International Court of Justice did not decide upon the validity of the Vandenberg reservation. At the same time, however, the judgment delivered in the Norwegian Loans case (Norway v. France) suggests the conclusion that the Court recognized as valid an other also very disputed reservation, the subjective domestic jurisdiction reservations joined to French declaration of acceptance. In his separate opinion attached to the judgment in that case Judge Lauterpacht points out that an eventual decision of the Court holding that a declaration of acceptance including the above mentioned reservation would also have a bearing on the declarations by a number of States which have had no opportunity to express their view on the matter. According to the British judge, under Article 63, of the Statute the Court would have had to recognize the right of intervention for those States which had included the said reservation in their declarations. Since it failed to do so, the States concerned may take the position that by virtue of Article 59, of the Statute the Court's decision is limited to the present case and may reserve themselves the right to express their views on this question in an another occasion. $^{52}$

Those who challenge the International Court of Justice for having failed to take a different stand on the question of the validity of reservations with rather disputable contents are undoubtedly right at first glance, but if one examines this problem more carefully and probes into it in light of the Court's possible findings on the matter, one must admit that the International Court of Justice was right to refrain from taking a definite stand on these delicate issues.

Had the Court decided that the multilateral treaty reservations or the subjective domestic jurisdiction reservations or the declarations containing such limitations were valid, it would obviously had exposed itself to sharp criticism on the one hand and would have undermined its own prestige and authority on the other. In addition, a definite stand of the International Court of Justice on clearly accepting as valid the contested reservations and the declarations accepting compulsory jurisdiction and containing such reservations would by

\footnotetext{
${ }^{52}$ Case of Certain Norwegian Loans. Judgment of July 6th, 1957. Separate Opinion of Sir Hersch Lauterpacht. ICJ Reports, 1957. 63-64.
} 
all means have afforded for States a kind of "encouragement" to incorporate such limitations in their declarations of acceptance.

The other avenue open to the Court would have been a pronouncement on the invalidity of declarations accepting compulsory jurisdiction and containing disputed limitations to or reservations.

Abrogation in their entirety compulsory jurisdiction declarations containing subjective domestic jurisdiction reservations or multilateral treaty reservations would have resulted in the Court depriving such declarations of acceptance even of the small fraction of legal effect they have retained despite these reservations in respect to the compulsory jurisdiction of the International Court of Justice. Pronouncing the invalidity of declarations containing such reservations would have operated to rule out even the theoretical possibility of the Court's compulsory jurisdiction coming into play over matters not affected by the reservations or, should the parties still not invoke the said reservation for some reason, that of the Court deciding the legal dispute submitted to it. 